DEPARTMENT OF THE INTERIOR UNITED STATES GEOLOGICAL SURVEY

\title{
AEROMAGNETIC MAP OF THE SOUTH CANAAN QUADRANGLE AND PARTS OF THE CORNWALL AND ASHLEY FALLS QUADRANGLES, LITCHFIELD COUNTY, CONNECTICUT
}

\author{
GEOPHYSICAL INVESTIGATIONS \\ MAP GP-64:1
}

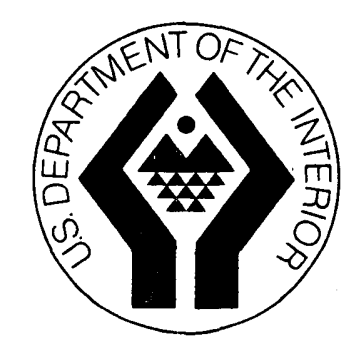

PUBLISHED BY THE U. S. GEOLOGICAL SURVEY 